

\title{
IIUNIVERSITY OF WYOMING
}

\section{National Park Service Research Center}

19TH ANNUAL REPORT 1995

\author{
EDITED BY \\ HENRY J. HARLOW \\ PROFESSOR \\ DEPARTMENT OF ZOOLOGY AND PHYSIOLOGY \\ UNIVERSITY OF WYOMING \\ DIRECTOR UW-NPS RESEARCH CENTER
}

MARYANNE HARLOW

REFERENCE LIBRARIAN

UNIVERSITY OF WYOMING LIBRARIES

UNIVERSITY OF WYOMING 


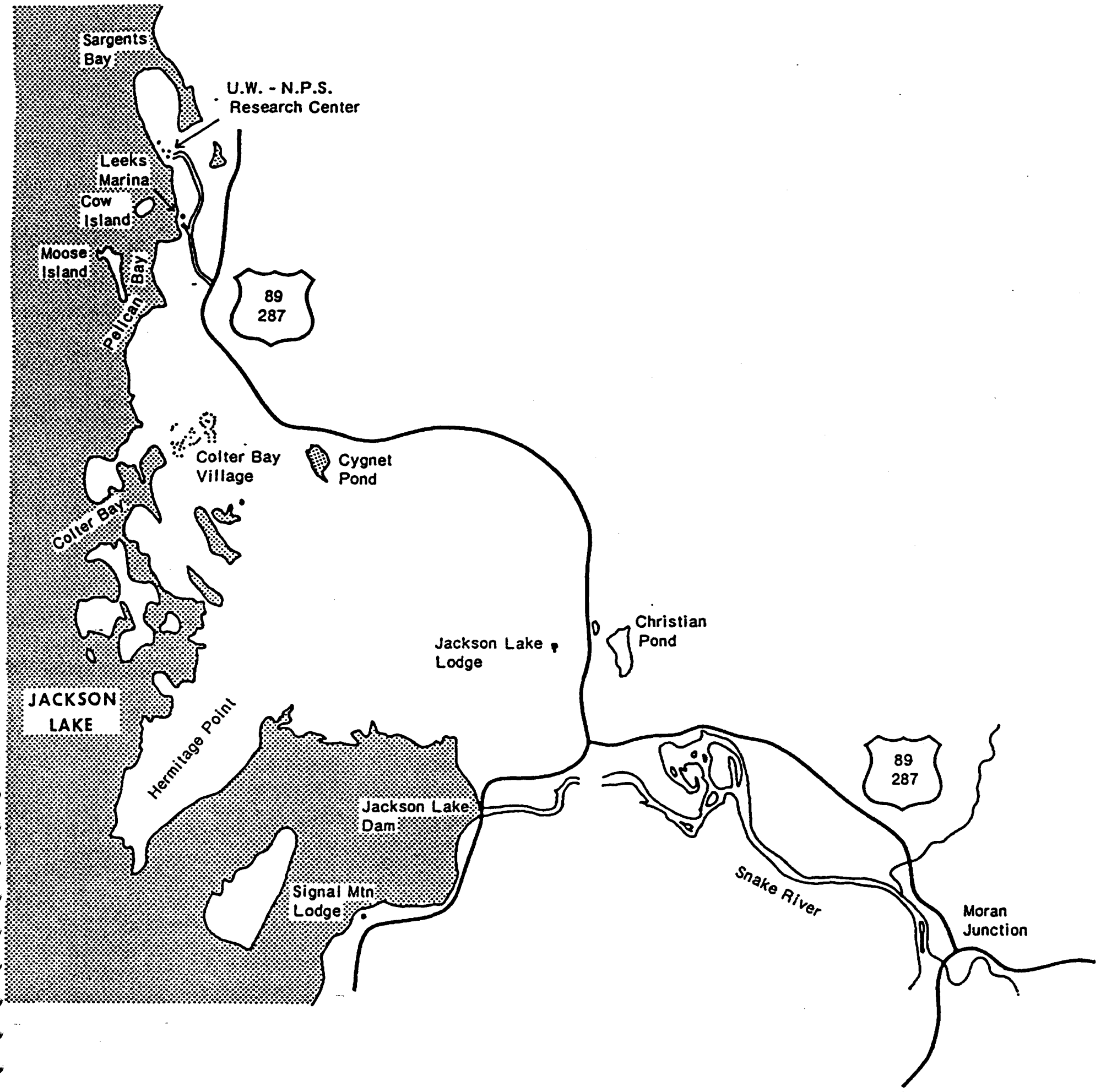

Box 3166 University Station

Laramie. Wyoming 82071

Telephone: $(307) 766-4207$ or 4227
Box 170

Moran, Wyoming 83013

Telephone: $(307) 543.2463$ 


\section{UUWYOMING}

\section{National Park Service Research Center}

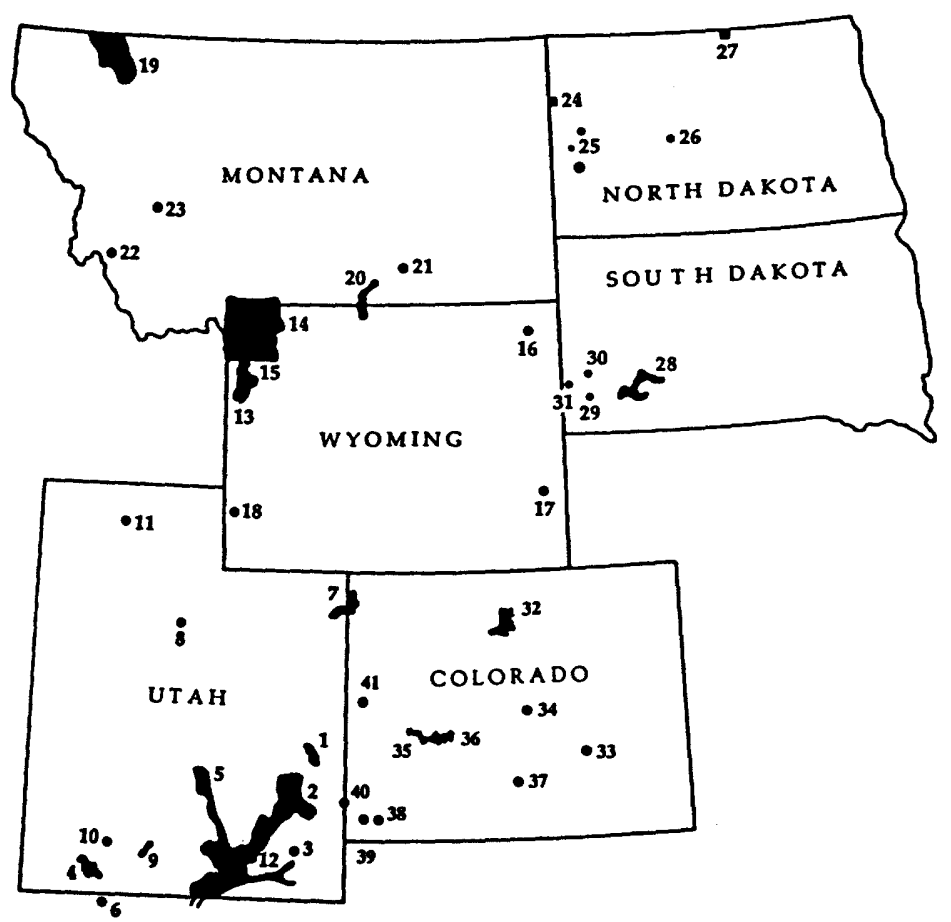

\section{+ UTAH}

1. Arches National Park

2. Canyonlands National Park

3. Natural Bridges National Monument

4. Zion National Park

5. Capitol Reef National Park

6. Pipe Spring National Park

7. Dinosaur National Monument

8. Timpanogos Cave National Monument

9. Bryce Canyon National Park

10. Cedar Breaks National Monument

11. Golden Spike National Historic Site

12. Glen Canyon National Recreation Area

19th ANNUAL REPORT 1995

$\uparrow$ WYOMING

13. Grand Teton National Park

14. Yellowstone National Park

15. John D. Rockefeller, Jr. Memorial Parkway

16. Devils Tower National Monument

17. Fort Laramie National Historic Site

18. Fossil Butte National Monument

\section{MONTANA}

19. Glacier National Park

20. Bighorn Canyon National Recreation Area

21. Little Bighorn Battlefield National Monument

22. Big Hole National Battlefield

23. Grant-Kohrs Ranch National Historic Site

\section{NORTH DAKOTA}

24. Fort Union Trading Post National Historic Site

25. Theodore Roosevelt National Park

26. Knife River Indian Villages National Historic Site

27. International Peace Garden

\section{$\rightarrow$ SOUTH DAKOTA}

28. Badlands National Park

29. Wind Cave National Park

30. Mount Rushmore National Memorial

31. Jewel Cave National Monument

\section{COLORADO}

32. Rocky Mountain National Park

33. Bent's Old Fort National Historic Site

34. Florissant Fossil Beds National Monument

35. Black Canyon of the Gunnison National Monument

36. Curecanti National Recreation Area

37. Great Sand Dunes National Monument

38. Mesa Verde National Park

39. Yucca House National Monument

40. Hovenweep National Monument

41. Colorado National Monument 


\section{Contents}

PAGE

Steering Committee -vii

INTRODUCTION ix

FeAtURE ARTicle $-1$

Remote Sensing of Coniferous Forest

Structure in Grand Teton National Park

C. Blodgett \& M. Jakubauskas $-3$

Research Project Reports $-9$

Grand Teton National Park

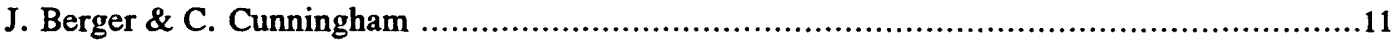

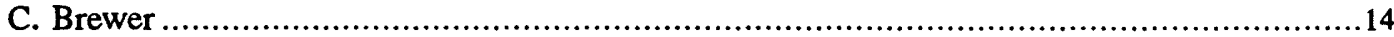

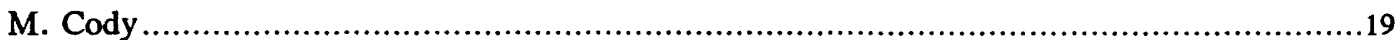

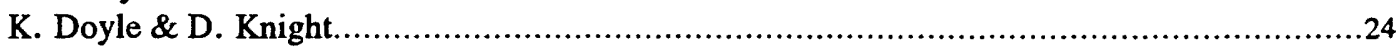

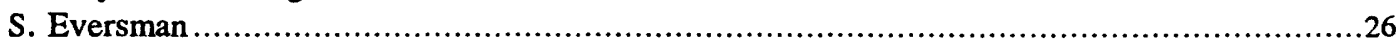

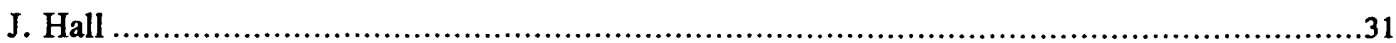

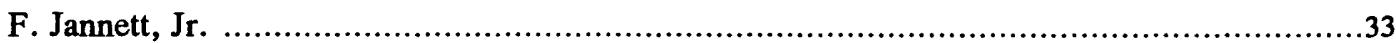

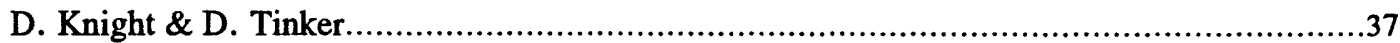

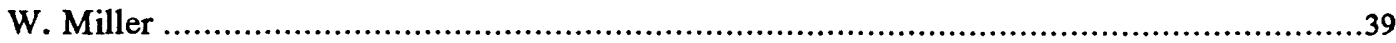

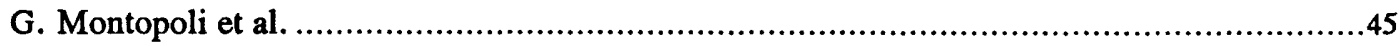

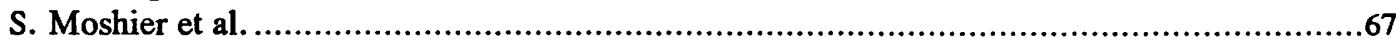

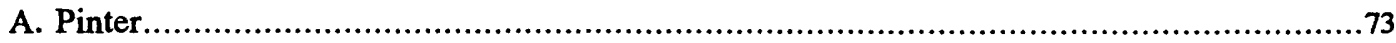

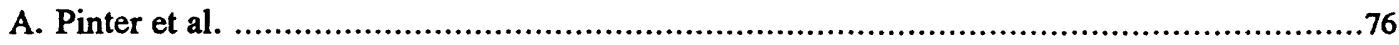

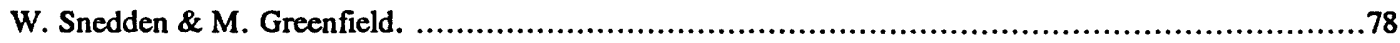

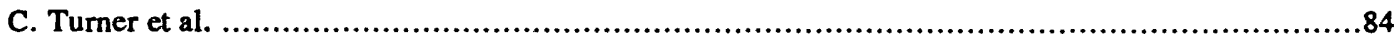

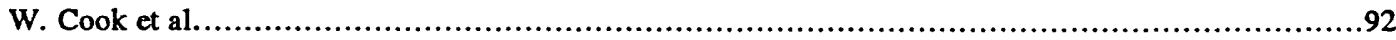

Grand Teton National Park and Yellowstone National Park

W. Duffy 


\section{UW-NPS ReSEARCH CENTER PERSONNEL}

HENRY J. HARLOW † DIRECTOR

KAREN K. NOLAND †OFFICE ASSOCIATE

RICHARD P. VIOLA $\uparrow$ CARETAKER

\section{STEERING COMMITTEE}

RONALD BEISWENGER

GEOGRAPHY AND RECREATION + UNIVERSITY OF WYOMING

STEVEN BUSKIRK

DEPARTMENT OF ZOOLOGY AND PHYSIOLOGY $\downarrow$ UNIVERSITY OF WYOMING

HENRY HARLOW

DIRECTOR $\uparrow$ UW-NPS RESEARCH CENTER

FREDERICK LINDZEY

WYOMING COOPERATIVE RESEARCH UNIT $\uparrow$ UNIVERSITY OF WYOMING

RONALD MARRS

GEOLOGY AND GEOPHYSICS $\uparrow$ UNIVERSITY OF WYOMING

ROBERT SCHILLER

SCIENCE RESOURCE MANAGEMENT $\downarrow$ GRAND TETON NATIONAL PARK

JOHN VARLEY

NATURAL RESOURCE COORDINATOR $\uparrow$ YELLOWSTONE NATIONAL PARK 


\section{INTRODUCTION}

\section{ANNUAL REPORT}

During the period of this report the University of Wyoming-National Park Service (UWNPS) Research Center supported and administered research in the biological, physical and social sciences performed in national parks, monuments, and recreation areas in Wyoming and neighboring states. The UW-NPS Research Center solicited research proposals from university faculty or fulltime governmental research scientists throughout North America via a request for proposals. Research proposals addressed topics of interest to National Park Service scientists, resource managers, and administrators as well as the academic community. Studies conducted through the Center dealt with questions of direct management importance as well as those of a basic scientific nature.

The Research Center continues to consider unsolicited proposals addressing applied and basic scientific questions related to park management. Research proposals are distributed to nationallyrecognized scientists for peer review and are also reviewed and evaluated by the Research Center's steering committee. This committee is composed of University faculty and National Park Service representatives and is chaired by the Director of the UW-NPS Research Center. Research contracts are usually awarded by the middle of March.

The UW-NPS Research Center also operates a NPS-owned field research station in Grand Teton National Park. The research station provides researchers in the biological, physical, and social sciences an enhanced opportunity to work in the diverse aquatic and terrestrial environments of Grand Teton National Park and the surrounding Greater Yellowstone Ecosystem. Station facilities include housing for up to 40 researchers, wet and dry laboratories, a library, herbarium, boats, and shop accommodations. The research station is available to researchers working in the Greater Yellowstone Ecosystem regardless of funding source, although priority is given to individuals whose projects are funded by the Research Center.

Special acknowledgement is extended to Ms. Karen Noland, Office Associate, for her skills and dedication to the Research Center which were a vital contribution to this publication.

\section{RESEARCH PROJECT REPORTS}

The following project reports have been prepared primarily for administrative use. The information reported is preliminary and may be subject to change as investigations continue. Consequently, information presented may not be used without written permission from the author(s). 


\section{FeATURE ARTicle}


UNIVERSITY OF WYOMING

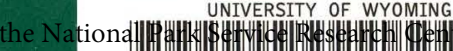

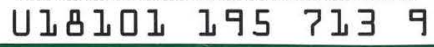




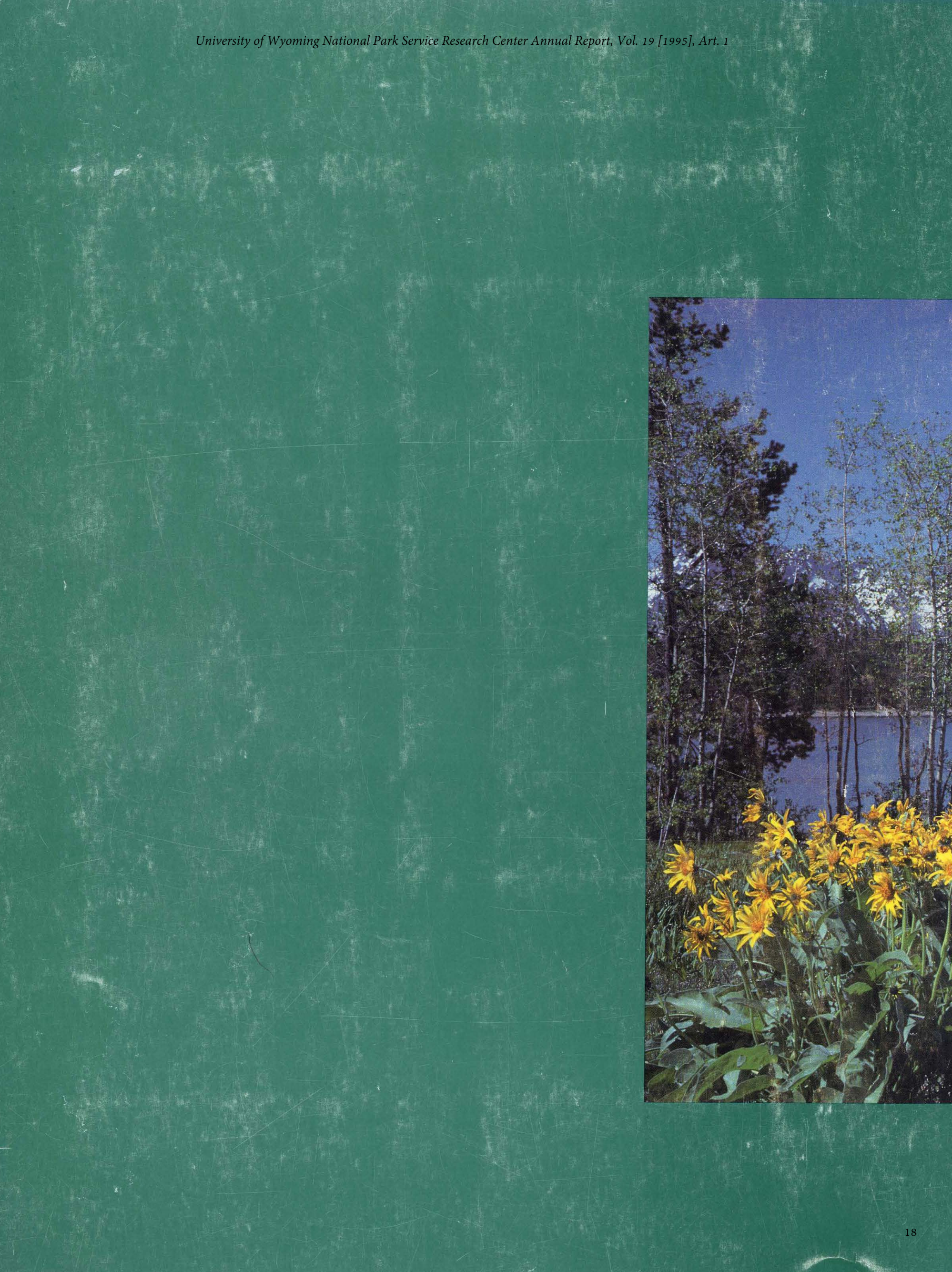

